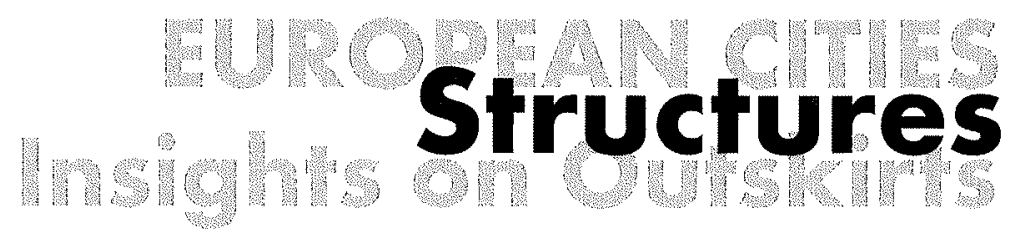

Edited by Axel Borsdorf and Pierre Zembri 


\section{Table of Contents}

ON THE WAY TO POST-SUBURBIA?

Changing structures in the outskirts of European cities

Axel Borsdorf

TRADITIONAL AND NEW MODELS EXPLAINING URBAN AND REGIONAL

FORM AND CHANGE

Case Helsinki

Pekka Lahti

MAPPING THE UNMAPPED, SEEING THE UNSEEN

Maresa Schumacher, Michael Koch

COMPARING THE MORPHOLOGY OF URBAN PATTERNS IN EUROPE

A Fractal Approach

Pierre Frankhauser

TRANSPORT NETWORK STRUCTURES AND OUTSKIRTS OF EUROPEAN CITIES

Pierre Zembri, Aimo Huhdanmaki

COMMERCIAL AREAS

IN THE OUTSKIRTS OF EUROPEAN CITIES

Locations and structures

Axel Borsdorf

CULTURE AND URBAN DEVELOPMENT

New cultural infrastructures in the outskirts of Vienna and Paris

Walter Rohn

PARALLELS AND DIFFERENCES IN THE OUTSKIRTS OF EUROPEAN CITIES

A methodological reflection and a comparative matrix

Axel Borsdorf, Stefano Crivelli, Christodoulos Demetriou, Pierre Frankhauser, Paolo Giovannini, Anna-Johanna Klasander, Michael Koch, Maresa Schumacher, Pierre Zembri 


\title{
CULTURE AND URBAN DEVELOPMENT
}

\author{
New cultural infrastructures \\ on the outskirts of Vienna and Paris
}

\begin{abstract}
Walter Rohn
Institute for Urban and Regional Studies, Austrian Academy of Sciences, Austria; walter.rohn@oeaw.ac.at
\end{abstract}

\begin{abstract}
Culture-orientated strategies, implemented at city or at local level, are increasingly recognised as catalysts for urban development. Within the given framework, cultural projects act as tools for the physical, spatial, economic and social development of cities. The Bastille opera in Paris, Bilbao's Guggenheim museum, the Temple Bar district in Dublin, London's Tate Modern and Zurich West are among Europe's best-known cultural projects. This article deals with new projects at local level and with cultural infrastructures in fringe districts of Vienna and Paris. The first case-study on Vienna presents the annual arts fair "Soho in Ottakring". The visitors survey reveals that the level of contentment with the peripheral district's overall cultural supply is low and that there is demand for additional facilities. The second case-study deals with the cultural scene of the $20^{\text {th }}$ district in Paris and shows that gentrification processes in the eastern parts of the city have led to the commercialisation and streamlining of cultural venues. The concluding section evaluates the cultural facilities' impact and works out a tentative typology of possible effects on peripheral areas' development.
\end{abstract}

\section{Keywords}

New cultural facilities, Cultural infrastructures, Outskirts of Vienna and Paris, Fringe areas, Urban development, Urban regeneration, Typology of effects. 


\section{Introduction}

Western industrialised countries and especially cities currently face a tremendous cultural boom. This includes the arts and their presentation (theatres, opera houses, museums, exhibition spaces as well as art, music and film festivals) in the strict sense of the word, creative industries, cultural tourism etc. in the broader sense. The Canadian Municipal Cultural Planning Project links the cultural boom to urban development: "The arts and culture are increasingly recognized as essential to prosperous and vibrant cities in the twenty-first century." (MCPP, 2003)

In the US the debate on culture and urban regeneration already began in the 1970s. "In many US cities the interests of arts organisations seeking new homes and funding coalesced with those of politicians attempting to relaunch downtown areas, and developers wishing to use arts venues, museums and leisure facilities as a means of adding value to office, housing and retail schemes in central districts." (Bianchini, 1993: 5). During the 1980s the discourse on culture-orientated strategies for urban development first spread to the UK and afterwards to the Continent.

At the beginning of the twenty-first century, the use of cultural projects as catalysts for urban development represents an established strategy. Within that strategy cultural projects act as tools for the physical, spatial, economic and social development of cities. Recent concepts of the issue are "culture-orientated approaches to urban revitalization" (Griffiths, 1995: 255), "entertainment-led regeneration" (McCarthy, 2002: 105), "cultural upgrading policy" (Seo, 2002: 114) or "cultural flagship projects" (Bianchini, 1993: 5).

According to the primary aims culture-orientated strategies for urban development can be implemented at city or at district level (see chapter 2). Within the European context, the Bastille opera in Paris, Bilbao's Guggenheim museum, the Temple Bar district in Dublin, London's Tate Modern and Zurich. West represent the best-known cultural projects. From Austria the presentation of Graz as European Capital of Culture 2003, the Museum quarter in Vienna and the new Lentos museum in Linz can be cited as relevant examples.

This paper presents first results of a current research project on culture and development of urban fringe areas ${ }^{1}$. More specifically the project deals with new cultural facilities on the outskirts of cities. Until the early 1990s, the peripheral districts of Vienna suffered from a massive lack of cultural infrastructures. Since the mid 1990s, a range of new cultural facilities has been created in this area. For the most part these new venues are grass-roots projects with relatively low scope. The respective cultural policy and the support by the municipality have yet to be developed. Following the study on Vienna, a second case-study deals with the cultural scene in a peripheral district of Paris.

At the outset, two basic definitions should be given: the first refers to culture. The term culture is used in various contexts, e.g. there are the philosophical, anthropological, semiotic-linguistic, aesthetic or historical dimensions. Among the many definitions of culture the one proposed by 
Marshall Salins (University of Chicago) in 1995 and subsequently used by Unesco seems to be best suited here. Salins briefly defines culture as the "total and distinctive way of life of a people or society" (INST, 2003). The second definition concerns the new cultural facilities on the outskirts. They refer to recently - i.e. since the mid-1990s - established venues and festivals for music, theatre, cabaret, readings, exhibitions, installations, performances, media art, electronic art and film in the fringe areas.

The paper's forthcoming chapters are organised as follows: Chapter 2 gives a comprehensive overview of the theoretical assumptions, the basic research questions and the research design of the study. Chapters 3 and 4 present two case-studies on new cultural facilities on the outskirts of Vienna and Paris. In the concluding chapter 5 recent cultural developments in the two cities' fringe areas are summarised and compared. Finally, a typology of the cultural facilities' effects on the development of peripheral areas is attempted.

\section{Theoretical starting point of the study}

The research project on culture and urban development is based on the following theoretical underpinning. As stated above, culture-orientated strategies for urban development can be implemented at city level or at the local level (quarters, districts, boroughs, neighbourhoods etc.). At city level, "cultural facilities and resources (...) have (...) become increasingly important complementary factors in the competition between cities possessing similar advantages" (Bianchini.1993: 18). At this level, large-scale cultural projects are primarily employed to create new, positive images for cities, which are of crucial importance for the competition of cities. Glasgow (European Capital of Culture in 1990) and Bilbao, for instance, have successfully shifted their external presentations from the image of an industrial centre to that of a cultural city. Liverpool, designated Capital of Culture for 2008, will try to follow these examples. Scientific literature holds many expressions for these strategies to enhance a city's image. McCarthy (2002: 105) has chosen the term "place marketing", Seo (2002: 114) writes on "urban re-imaging" and Zukin (1998: 27) analyses an "economy of symbols".

Cultural initiatives at the local level - which are at the focus of this paper - primarily aim at upgrading disadvantaged areas or districts. In Europe these are frequcntly pcripheral areas of cities. Among the possible effects of this improvement of the local cultural infrastructure are a certain cultural self-reliance of fringe areas, the democratisation of culture, an improvement of living conditions, the integration of different parts of the population, the creation of a distinct identity of the outskirts and a stronger identification of the population with their habitat. 
In practical work it is often difficult to classify the specific cultural projects and to relate them either to the city or the local level. The boundaries between these two levels are often blurred. Possible differentiations exist according to the scope and the primary purpose of the ventures. Large-scale cultural projects - regardless of the part of the city in which they are situated - are frequently designed as flagship projects for the enhancement of a city's image or serve the needs of the population of the entire city. Smaller venues mostly serve the needs of the local population and an upgrading of distinct city areas.

From the broad scientific work on culture and urban development, the findings of three studies shall be briefly summarised. Seo (2002) presents projects in Manchester and Glasgow as examples of a cultural upgrading policy. In the 1990s, new cultural initiatives were combined with housing schemes in these cities. McCarthy (2002) writes on recent developments in Detroit. In the last decade, theatres, sports stadiums and casinos were built or renovated in Detroit as part of a strategy of entertainment-led regeneration. In the early 1990s, arts and entertainment zones were created in the centre and in the harbour area of Bristol. Griffiths (1995) cites Bristol as an example for culture-orientated approaches to urban revitalisation.

The primary targets were met in all cities. Cultural and housing policies in Manchester and Glasgow succeeded in attracting young and prosperous residents. Detroit was able to halt processes of decline by establishing a certain feel-good factor and by strengthening civic pride. Cooperation between public, private and voluntary sectors was intensified in Bristol. Problems were mentioned by the authors with respect to the wider-ranging effects of cultural projects. Griffiths (1995) points out that the use of similar approaches (concert halls, theatres, museums and festivals) by many cities might lead to a standardisation of urban areas instead of individual cities achieving a distinct profile.

Within the framework of the project the following basic research questions will be answered.

Firśt: What are the basic characteristics of the new cultural initiatives? This relates to the major actors of the projects, legal structures, ways of financing, aims, different types of art presentation, networks and the specific location of the cultural facilities as well as to catchment areas of visitors and participants.

Second: Which are the driving forces of this cultural boom time on the outskirts of cities? Do push factors like processes of decentralisation or pull factors lie at the bottom of the establishment of new cultural venues? Among the latter might be residents' initiatives, a certain lack of cultural infrastructures in the peripheral areas, comparatively lower housing prices and rents or vacancies of shops and flats.

Third: In which ways are (new) cultural facilities contributing to a positive development of urban fringe areas and which recommendations (public support, building of networks) can be given for cultural policy and urban planning? 
In respect of the project's research method a combination of quantitative and qualitative methods was chosen. Among the methods applied are

- Compilation of official data on the cities and their administrative units (existing cultural infrastructures, distribution of residents, age structures, number of work places, income levels, housing stock, foreign population etc.),

- Inventory of cultural initiatives on the outskirts,

- Documentation of the most important new cultural facilities with a regular programme,

- Photographic documentation,

- Participatory observation,

- Survey of visitors to cultural facilities (questionnaire),

- In depth-interviews with main project actors (based on a fixed set of questions),

- Additional interviews with experts in the field of culture, urban planners and politicians,

- Comparative studies on European cities as well as

- Creation of a typology of new cultural venues on the outskirts.

\section{Case-study 1: New cultural infrastructures on the outskirts of Vienna}

\subsection{Overview}

Until the early 1990s, the outer districts of Vienna were more or less a blind spot as regards cultural infrastructure. The outer districts or outskirts of Vienna are the districts 10 to 23. Until that time most of the cultural institutions in Vienna like theatres, opera houses, concert halls, museums, exhibition spaces etc. were located in the inner districts. The outer districts' supply of cultural facilities merely offered a few locations: the castle of Schoenbrunn, two venues for big shows and concerts ("Wiener Stadthalle", "Kurhalle Oberlaa"), a few remaining cinemas, some medium-sized venues for music, cabaret, theatre etc. ("Szene Wien", "Rockhaus", "Kulisse", "Metropol" etc.) and the cultural programme presented by local museums, institutions of adult education, convention and youth centres.

In the mid 1990s, a boom of new cultural facilities set in on the fringes of Vienna. A lot of new venues - basically for the performing arts, the fine arts and film presentation - with a regular programme were established. The "Gloria Theater" (1 - see numbers in figure 1), 
"Orpheum" (7), the "Kabelwork" (12, a former cable factory), and the "Theater des Augenblicks" (20, theatre of the moment) present theatre and cabaret programmes. The jazz-club Dávis (4), the "Bank Austria Halle" (9), the "Sargfabrik" (13, coffin factory), "Café Concerto" (15) and "Vorstadt" (16) are basically venues for music events. The "Kulturkabinett" (3, chamber of culture), the arts fair "Soho in Ottakring" (18), the "Projekt" (19) and the action space "Augarten" (21) present various arts, the gallery "Art und Weise" (17) specialises in paintings and photographic work. In addition to these locations there are seven multiplex cinemas and chateau "Neugebaeude" (10), a venue for open-air film presentations.

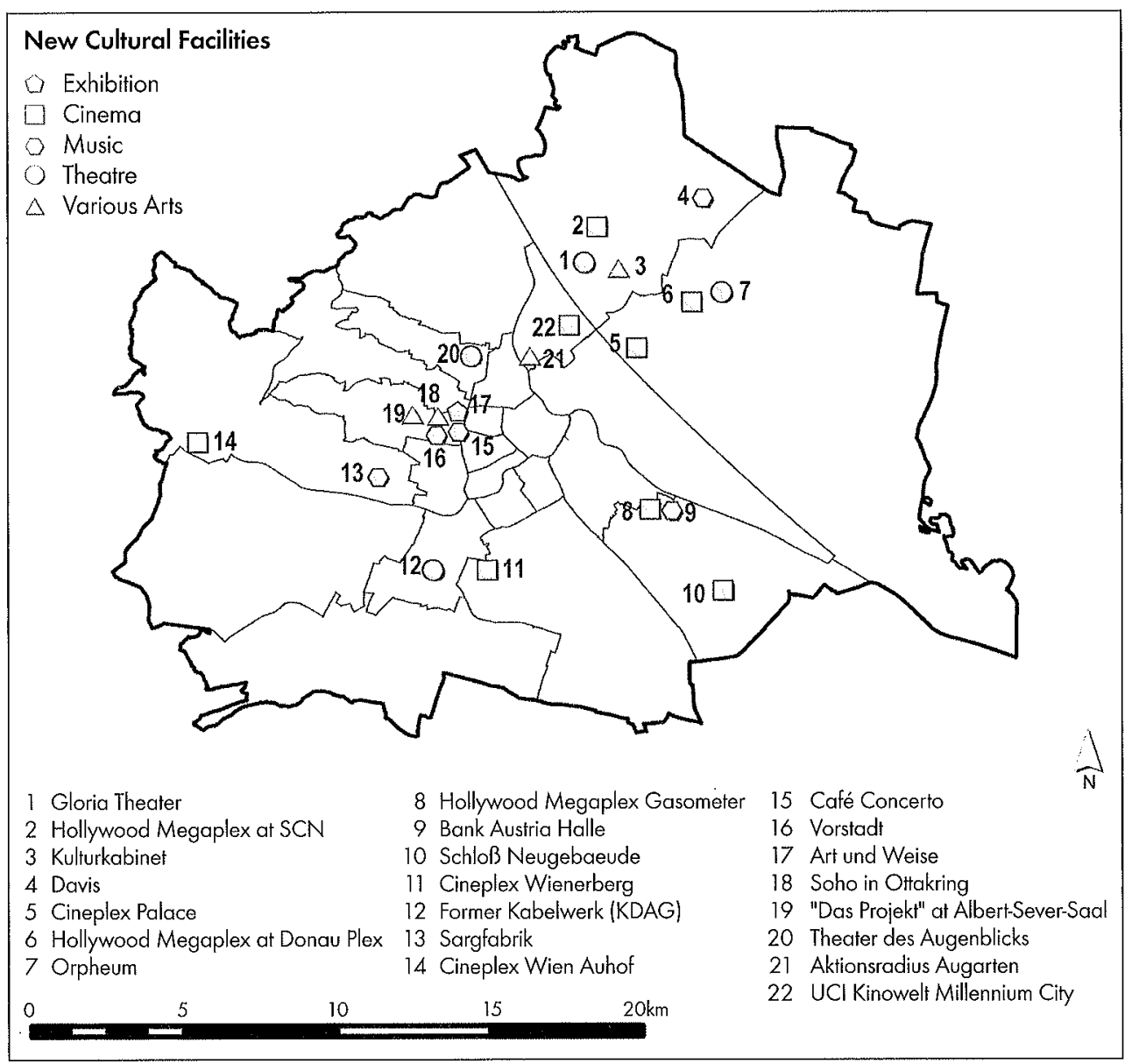

Source: "Falter", "Deliesse", "Kurier" and various internet sources

Conception: Walter Rohn - Cartography: Edgar Hagspiel - January 2004

Figure 1: New cultural facilities in the outskirts of Vienna with a regular programme 
The cultural facilities do not only differ in their artistic presentations but also in size and sources of finance. While the "Gloria Theater", "Bank Austria Halle" and the multiplex cinemas attract larger audiences, the "Kulturkabinett", jazz-club Davis, "Vorstadt" or "Art und Weise" are venues for presentations on a smaller scale. As regards financing, there are facilities with a high degree of public support (e.g. "Gloria Theater", "Projekt"), initiatives with mixed public-private financing ("Soho"), venues of the private-voluntary type ("Art und Weise", action space "Augarten") and commercial institutions like the multiplex cinemas. As figure 1 shows, some clusters of new cultural facilities are emerging in the $16^{\text {th }}$ district (in the West) and in the $21^{\text {st }}$ district (in the North).

In addition to the above-mentioned venues with a regular programme, the outskirts house a broad range of new locations that sporadically present cultural events (e.g. live music, cabaret, readings, exhibitions etc.). Special festivals for accordion, jazz and folk music or the open-air film presentations by "volxkino" - located at various places in the entire city - further contribute to the outskirts' cultural supply.

\subsection{The arts fair "Soho in Ottakring"}

The arts fair "Soho in Ottakring" usually takes place in spring in the "Brunnenmarkt" quarter (market area) in the 16th district of Vienna. The "Brunnenmarkt" quarter and the eastern parts of the 16th district in general are partly run-down areas in proximity to a heavily congested main road (the "Guertel"). Especially in the district's eastern parts, the proportion of foreign population (mainly from Turkey) is quite high.

In the 1990s, young artists chose this multicultural quarter as a residential and a working area because of relatively low rents and housing prices. The artists' scene in "Ottakring" is depicted in Martin Praska's Art Novel (2001). Ula Schneider, who established the "Soho" festival in 1999, quotes developments in New York's SoHo (see Zukin, 1998) as a point of reference and indicates that the basic reason for the establishment of "Soho" in the 16th district was "to do something in the residential area" (interview with Ula Schneider, 28. 5. 2001). From an institutional point of view, "Soho" and other new cultural initiatives in the 16th district might as well be seen as a spill-over from an urban regeneration project at the nearby main road.

The basic idea of "Soho" was to present art exhibitions and events in vacant and still used shops. Additional events take place in the streets or at "Yppenplatz", the area's central square. By creating exhibition space for young artists, "Soho" also contributes to the regeneration of the "Brunnenmarkt" quarter. In addition to state and communal funding, the arts fair is sponsored by Vienna's chamber of commerce (interview with Ula Schneider). "Soho's" artistic programme basically includes painting, object art, installations, photography, film, video, media art, electronic art, readings and music (Schneider, 2003). 
The fieldwork on "Soho in Ottakring" was carried out in spring 2003. During the art fair's opening ceremony and in the course of two other artistic events, the visitors' opinions were gathered by means of a short questionnaire. The random sample contains 128 questionnaires. Further research work aims to ask visitors of the district's other new cultural facilities as well. Table 1 gives the basic characteristics of the studied visitors to Soho. The data show that the festival's audience is quite young. 40 percent of the visitors are younger than 30 and another 39 percent between 30 and 40 years of age. Table 1 further indicates that the audience is well-educated. 48 percent of the visitors hold a degree at university level (Survey "Soho 2003").

\begin{tabular}{|l|c|c|}
\hline Variables & Percentage & $\mathbf{n}=$ \\
\hline Gender & & $\mathbf{1 2 7}$ \\
\hline Male & 44 & $\mathbf{1 2 6}$ \\
\hline Female & 56 & \\
\hline Age structure & & \\
\hline$<30$ years & 40 & $\mathbf{1 2 7}$ \\
\hline$\geq 30 \leq 40$ years & 39 & \\
\hline$>40$ years & 21 & \\
\hline Education & & \\
\hline Secondary modern school & 4 & \\
\hline Grammar school & 9 & \\
\hline Studies of applied sciences & 39 & \\
\hline University & & \\
\hline Residential districts & 46 & \\
\hline Inner districts (1 to 9) & 54 & \\
\hline Outer districts (10 to 23 ) & & \\
\hline
\end{tabular}

Source: Survey "Soho 2003"

Table 1: Basic characteristics of visitors to the arts fair "Soho in Ottakring 2003

One of the most important questions relates to the catchment areas of the cultural facilities' and event's visitors. Do these new venues and events basically serve the needs of the local population or are the visitors coming from all over Vienna? In other words: do these new cultural initiatives basically form part of the local cultural infrastructure or are they destinations of a cultural tourism within the city and agglomeration boundaries? In the case of "Soho" the answer is quite clear (see figure 2). Only 13 percent of the visitors of "Soho" live in the $16^{\text {th }}$ district. While another 14 percent of the audience come from the neighbouring outer districts, 18 percent stem from the neighbouring inner districts of Vienna. That means that the majority of "Soho's" visitors (55 percent) comes from remote parts of the city (Survey "Soho 2003"). 


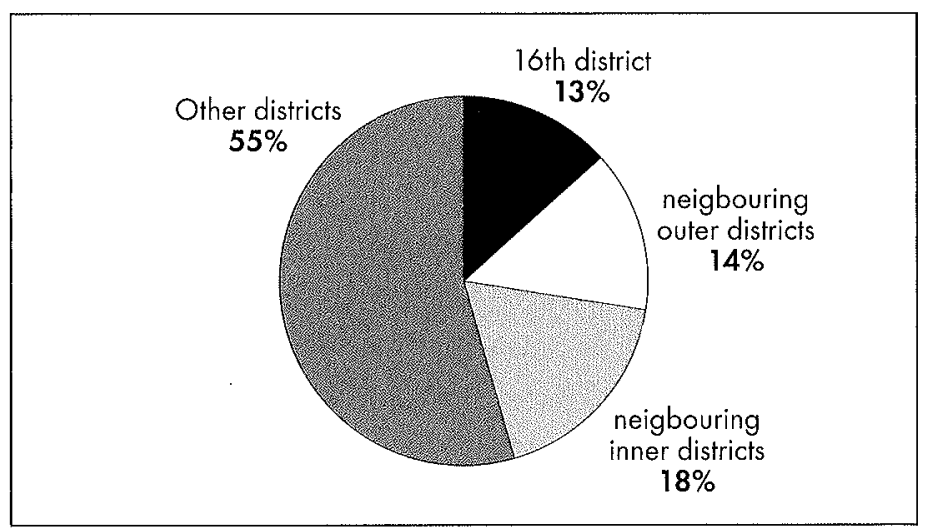

Source: Survey "Soho 2003"

Figure 2: Catchment areas of visitors to arts fair "Soho in Ottakring"

Another relevant question relates to the cultural activity spaces of the festival's visitors. Due to the ongoing lack of cultural infrastructure in the outskirts of Vienna, 86 percent of the visitors primarily take part in cultural events in the better-equipped inner districts of the city. However, there is a slight differentiation between visitors from the core and those from the peripheral districts, the latter being more interested in cultural events on the outskirts. With 38 percent of the visitors indicating a high satisfaction with "Soho's" cultural programme and 51 percent choosing the answer "for the most part", the degree of satisfaction with the festival's programme is quite high (Survey "Soho 2003").

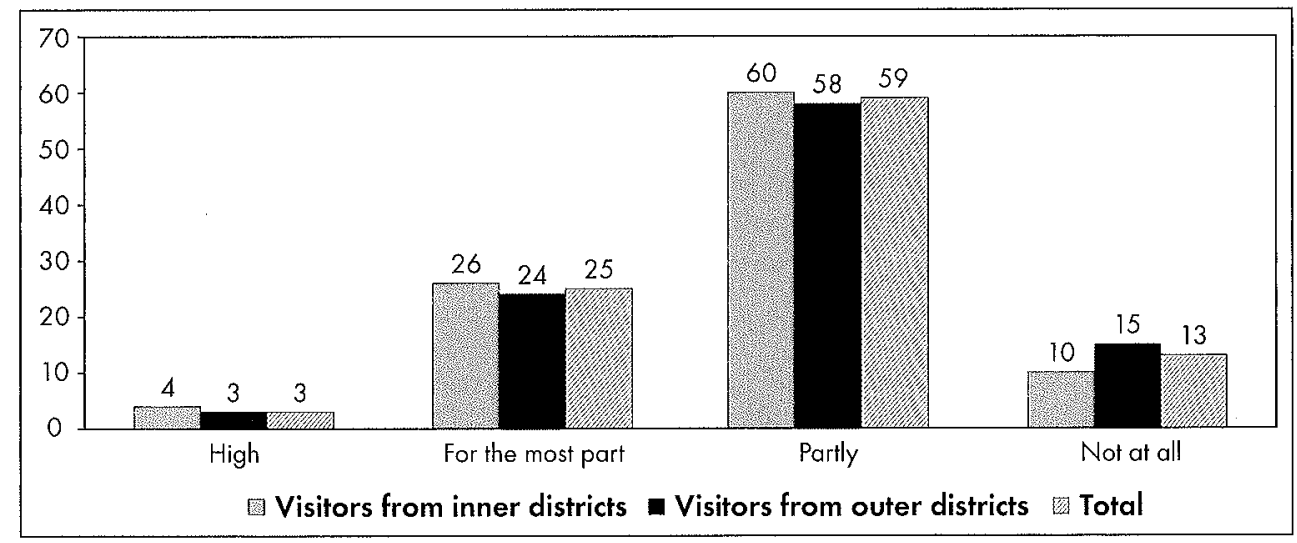

Source: Survey "Soho 2003"

Figure 3: Visitors' satisfaction with the general cultural supply in the outskirts (percentages) 
Comparatively low is the visitors' satisfaction with the outer districts' cultural infrastructure in general (see figure 3). While a mere 3 percent of the participants show great and 25 percent overall satisfaction with the outer districts' cultural supply, a majority of 59 percent is only partly content. Interesting to note that the share of visitors who do not show the slightest satisfaction with the cultural programme is higher among people from the outskirts than among those from the core districts. Being dissatisfied with the outskirts' cultural supply, 30 percent of all visitors to "Soho" want additional music programmes, 23 percent more exhibitions and 21 percent more film programmes (Survey "Soho 2003").

People were also asked about the possible effects of (new) cultural venues on the development of fringe districts in Vienna. The first question related to the improvement of living conditions (see figure 4). 79 percent of the visitors rated the contribution of cultural facilities to the improvement of living conditions in the outskirts of Vienna as very important and another 18 percent as medium important. Visitors from the outer districts show even more optimism than those from the centre. A bit less positive is the visitors' view on the relevance of cultural facilities for the integration of different parts of the population. 63 percent of the visitors deem this contribution very important and 28 percent medium important. Visitors from fringe districts are comparatively less convinced of the venues' relevance for integration than those from the central parts of the city (Survey "Soho 2003").

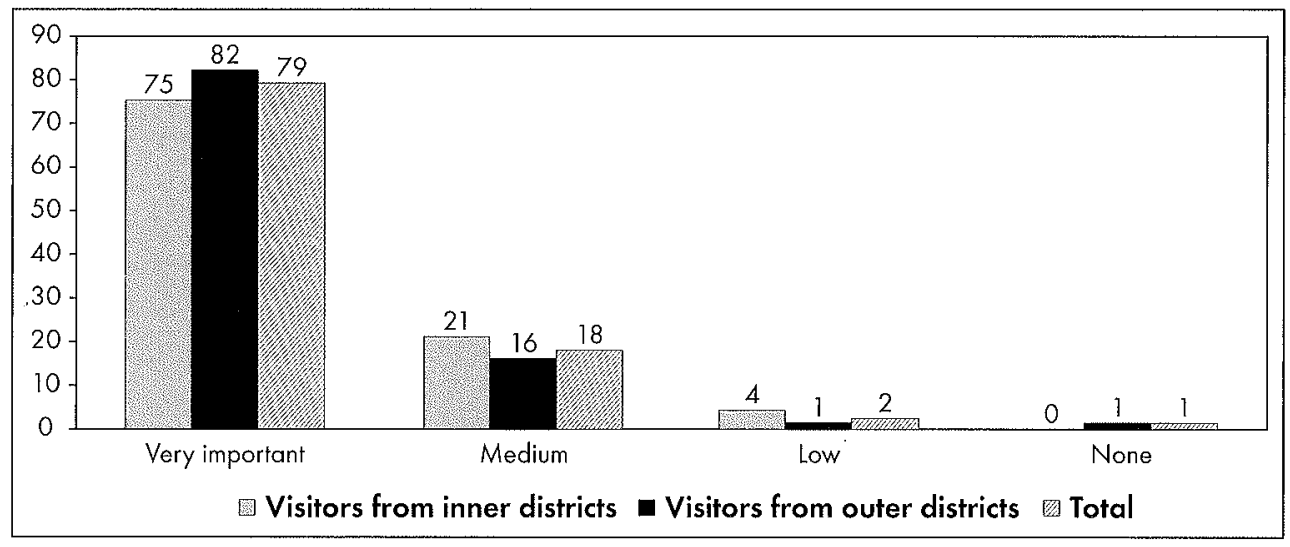

Source: Survey "Soho 2003"

Figure 4: Contribution of cultural facilities to the improvement of living conditions (percentages)

In recent years, "Soho in Ottakring" has become the $16^{\text {th }}$ district's best-known cultural event. Following the model of "Soho" in 2002, another annual arts fair was established in the area. On the basis of the lively scene of artists and cultural facilities, the district municipality has created a label "Ottakring culture" and tries to market the area as an arts district (Art Position, 2003). 


\section{Case-study 2: The cultural scene of the $20^{\text {th }}$ district of Paris}

\subsection{Overview}

Visitors to Paris might get the impression that the whole city of Paris is packed with cultural institutions or facilities like museums, exhibition spaces, theatres, opera houses, cinemas, concert halls, music clubs, venues for media and electronic arts, arts fairs and festivals. But there are huge differences in quality and density of the cultural infrastructure. In Paris decentralisation of major cultural institutions already started in the late 1980s with the Bastille opera in the $12^{\text {th }}$ district and the "Musée des Sciences et de l'Industrie" (19th). The new National Library (13 $\left.{ }^{\text {th }}\right)$, the City of Music and the Grand Hall at la Vilette (both $19^{\text {th }}$ ) represent recent examples of the decentralisation of major cultural institutions. Nevertheless it is still the inner parts of the French capital that are best equipped with cultural infrastructure. Compared to that the density of the peripheral districts' web of cultural facilities is still low.

Because of its structural deficiencies, the $20^{\text {th }}$ district in the East of Paris ("Ménilmontant") was chosen for a case-study on cultural facilities in the fringe districts of the French capital (see figure 5). In the East, the district is boarded by the ring road Boulevard Périphérique. The northern part of the district, lower "Belleville", is an urban regeneration area and forms part of the famous quarter "Belleville" (Coy 2003). "Belleville's" multicultural ambience is impressively depicted in Daniel Pennac's novels. The $20^{\text {th }}$ district's municipality is located at Gambetta square, the centre of the district. It fits well into the picture that the district's best-known tourist site is the cemetery "Père Lachaise".

The following institutions and facilities make up the $20^{\text {th }}$ district's cultural infrastructure: "MK2 Gambetta", which belongs to the MK2 cinema-chain is the area's only cinema. "Théâtre National de la Colline" is a well-known and acclaimed state theatre. Apart from that the district houses a couple of medium-sized or small theatres like "Théâtre de l'Est Parisien" (see below), "Vingtième Théâtre", "Comédie de la Passarelle", "Théâtre de Ménilmontant", "Théâtre les Enfants Terribles" and "Théâtre des Quarts d'heure". "La Flèche d'Or" (see below) and cafes like "Lou Pascalou" or "Oh 20e" are venues for the presentation of live music. "Confluences - Maison des Arts Urbains" (theatre, performances, exhibitions, electronic art) and "La Maroquinerie" (see below) present various arts. Further cultural events are organised by artists associations like "Ateliers d'artistes de Belleville" or "Ateliers du Père Lachaise associés", by the district municipality or by the district's seven neighbourhood councils.

The "Maroquinerie" and the "Flèche d'Or", recently established and comparatively small, independent cultural initiatives, were chosen as examples for cultural facilities in the $20^{\text {th }}$ district. The medium-sized and mostly state subsidised "Théâtre de l'Est Parisien" was selected as a 
contrasting third facility to be studied in detail. In depth-interviews with representatives of the three venues were carried out. In addition, a representative of the $20^{\text {th }}$ district's municipality was interviewed. The research and fieldwork for the case-study on cultural facilities in the $20^{\text {th }}$ district of Paris was done in September 2002.

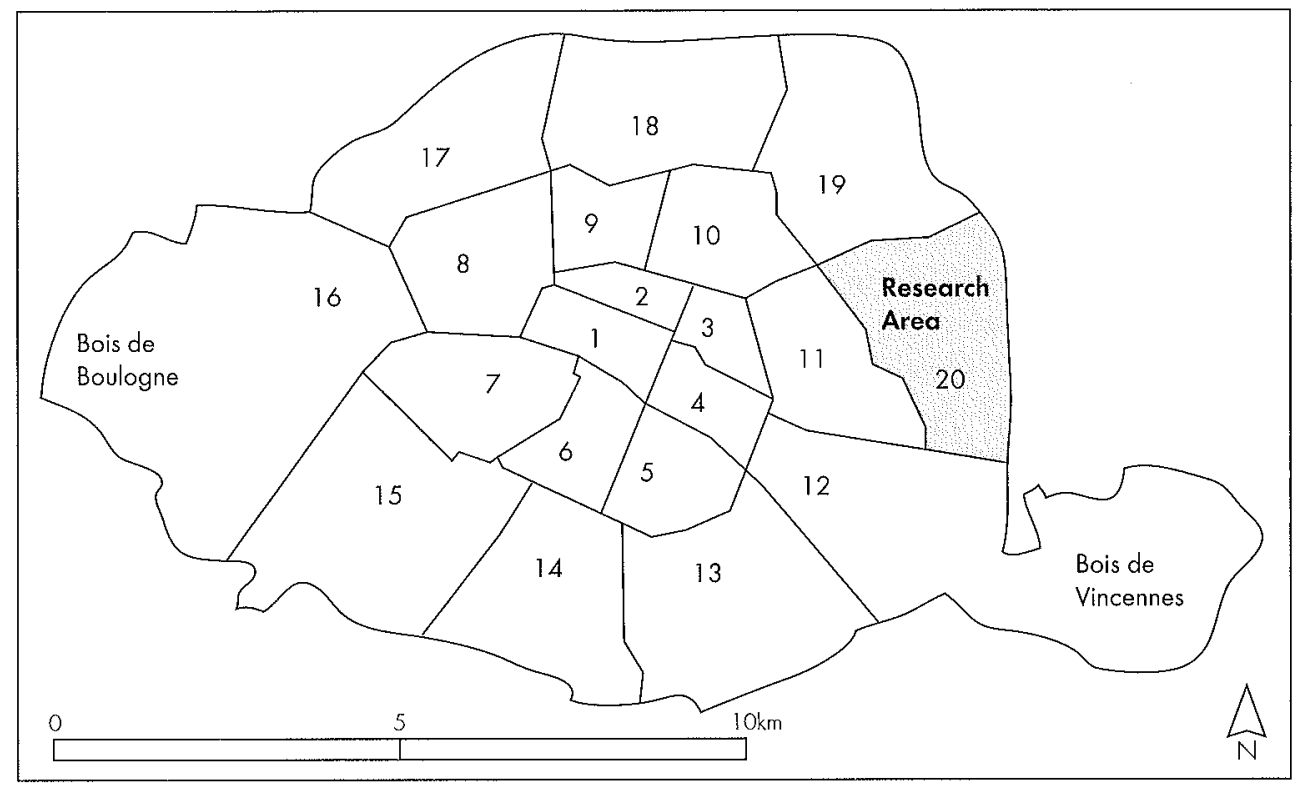

Source: Michelin 1994

Figure 5: Research area and administrative structure of Paris

\subsection{Three cultural facilities in the $20^{\text {th }}$ district and the district municipality's cultural activities}

"La Maroquinerie - Café Littéraire" at rue Boyer 23 is a small cultural facility presenting outstanding artistic productions in the fields of theatre, literature and music. From the outset it was the founders' intention to establish the venue in a "popular" quarter of Paris. After checking a few potential locations in some peripheral parts of Paris, the project initiators decided to launch the project in the $20^{\text {th }}$ district, at rue Boyer. The venue was opened in 1998 (interview with vicedirector Patricia Pailleaud, 13. 9. 2002). 
The "Maroquinerie" is settled on historic ground. From 1877 to 1939 rue Boyer was one of the locations of the workers cooperative "La Bellevilloise" which served the population in the $19^{\text {th }}$ and $20^{\text {th }}$ district. Among the cooperative's cultural activities were film, music and theatre presentations (Meusy.2001). Later a leather factory operated there, which eventually gave the cultural facility its name.

The "Maroquinerie's" current artistic programme is primarily based on theatre productions, readings and music-performances (folk, world, jazz etc.). In addition, discussions with artists, literary journals and scientific works are presented. The "Maroquinerie" has two rooms for artistic presentations at its disposal. Concerts, theatre productions and other major events take place at the main hall and attract up to 150 spectators. The "Café Littéraire" houses presentations of a smaller scope with approximately 65 visitors. Roughly half of the audience comes from the neighbourhood. During the summer months, a fine courtyard is also used for open-air events. An affiliated restaurant makes the stay at the "Maroquinerie" even more comfortable.

The cultural facility's financing is almost entirely based on private resources, i.e. ticket sales and revenues generated by the restaurant and the coffee bar. Flyers, posters and announcements in event magazines like Pariscope or Zurb@n promote the "Maroquinerie's" cultural programme. Since 2003 the venue also has its own web page: http://www.lamaroquinerie.fr/.

In 2003, Asterios Productions took over the "Maroquinerie's" management. In the course of that change the venue's cultural programme was commercialised and streamlined. Previous emancipatory elements of the programme like political discussions or the presentation of political journals were abandoned. This streamlining already reflects processes of gentrification in the East of Paris.

The live music venue "Flèche d'Or Café" (Golden Arrow Cafe) is also a facility with a special history. The "Flèche d'Or" at Rue de Bagnolet 102 is located at the "Gare de Charonne", an ancient train station of the abandoned circular railway "Petite Ceinture". In the early 1990s, some artists were squatting in the Charonne quarter of the $20^{\text {th }}$ district and came to know the disused railway station. The artists made a deal with SNCF, the French state railway, and adapted the site to their needs by erecting a small stage and installing the necessary electronic equipment. The "Flèche d'Or Café" opened its gates in 1995. According to da Rocha, one of the principal founders of the venue, "it was the location that chose its users" (interview with Manuel da Rocha, 13.9.2002).

The "Flèche d'Or" generates most of its revenues through the affiliated gastronomic services (bar, restaurant), the cheap entrance fees only make up a third of the venue's financing. Due to a close connection with local residents, a good deal of the cafe's visitors comes from the Charonne quarter or from the neighbouring communities across the Boulevard Périphérique.

Like the "Maroquinerie", the "Flèche d'Or" underwent a change of its cultural programme in 2003. The venues' programme was centred on music presentations, basically French folk, 
reggae, rock, hip hop, jazz and electronic music. Instead of one performance later in the evening the venue now offers two live events. The first music show to which the entrance is free starts at 6 p.m. and the second at 8:30 p.m. The venue's current programme is on display at http:// www.flechedor.com/.

The "Flèche d'Or's" previous programme contained more participatory elements like open scenes for amateur musicians, participation in a local television programme ("Télé Bocal") and political debates with representatives from Le Monde diplomatique, Attac etc. As in the previous case, the commercialisation of the music venue's cultural programme points to processes of gentrification.

By contrast, the "Théâtre de l'Est Parisien" (Theatre of the East of Paris) represents one of the district's oldest cultural facilities. The theatre was established in 1963, in the building of a former cinema, at Rue Malte-Brun 13-17. In 1984, the "Theâtre de l'Est Parisien" (TEP) moved within the district to Avenue Gambetta 159. In the mid-1980s, the "Théâtre National de la Colline" (National Theatre of the Hill) was founded at the original site of the TEP (interview with vice-director Claude Juin, 19. 9. 2002).

Guy Rétoré, the founder of the TEP, was born in the $20^{\text {th }}$ district. Therefore it was his ambition to establish his "popular theatre" or "neighbourhood theatre" in this district, on the outskirts of Paris. From the late 1960s to the early 1980s, the TEP was also involved in the political movements of that age (Denizot.1999).

The theatre at Avenue Gambetta has 400 seats, approximately 50 percent of the available tickets are sold. Since the TEP's financing is largely based on state subsidies, the theatre is in a position to offer subscriptions and special tickets at reduced fees. Until today the "Théâtre de l'Est Parisien" tries to keep close contacts to local residents and presents its "spectacles-baladeurs" (promenading performances) at workplaces, in libraries and schools. Special performances for children or for a young audience are offered regularly. The TEP is also presenting workshops for actors and writers and special readings. The theatre's current artistic director is Catherine Anne (interview with Claude Juin).

Unlike the two facilities discussed above, the "Théâtre de l'Est Parisien" did not change its cultural programme, only the visual presentation (new logo and new lettering at the entrance) was altered. The theatre's programme is promoted by posters, a seasonal programme and by announcements in event magazines. Since 2003, the TEP also has its own website (http:// www.theatre-estparisien.net/).

Due to the still very centralised nature of the French administration, the municipality of the $20^{\text {th }}$ district has only limited authority and limited resources in the field of culture. Subsidies to the district's cultural facilities are mostly granted directly by the Ministry of Culture, the regional authority of cultural affairs (DRAC) or by the city's municipality. The district municipality's cultural activities are therefore limited to smaller scale events. Once a year, in May and in June, the district municipality organises the arts festival "Le 20 $0^{\text {ième }}$ en Cultures" (the $20^{\text {th }}$ district in cultures), which involves all the cultural facilities and artists of the district. Additional activities 
are e.g. music contests and lectures on the arts. Further cultural activities are carried out by the district's seven neighbourhood councils ("conseils de quartier"). In September 2002, the neighbourhood council of Gambetta organized a fine "Fête Edith Piaf" in honour of the famous singer. All the cultural events taking place in the area are announced in "La Gazette", the monthly newsletter of the district municipality (interview with Nathalie Kaufmann, in charge of cultural affairs at the $20^{\text {th }}$ district, 19. 9. 2002). In 2003, the district municipality has also created a new website: http://www.mairie20.paris.fr/mairie20/jsp/Portail.jsp.

\section{Conclusions}

In the previous chapters new cultural infrastructures and trends on the outskirts of Vienna and Paris were presented. It must be said that in Paris decentralisation of cultural institutions started much earlier than in Vienna. As indicated above, the decentralisation of major cultural institutions in the French capital began in the late 1980s with the Bastille opera and the Museum of Science and Technology. The first example of the decentralisation of a major cultural institution (in the widest sense) in Vienna is the city's new Central Library, which opened in 2003. For the purpose of this contribution it seems most fruitful to sum up and to compare cultural developments in the two fringe districts of Vienna and Paris described above.

In the course of trends observable since the mid-1990s in many fringe districts of Vienna, a lively cultural ambience developed in the $16^{\text {th }}$ district. "Vorstadt", "Art und Weise" and "Café Concerto" are new cultural facilities with a regular programme. The "Club International" which basically offers readings, the gallery "Masc foundation" and the music venue "Bach" represent recent examples of locations presenting a more sporadic cultural programme. The cited facilities are all smaller scale grassroots projects.

Established in 1999, the arts fair "Soho in Ottakring" has become the districl's outstanding cultural venture. As the survey of visitors to "Soho" shows, the level of satisfaction with the festival's programme is quite high. By contrast, there is a high degree of dissatisfaction with the outskirts' cultural infrastructure in general. An interesting question relates to the catchment areas of the new cultural facilities' audience. Will these new venues and events basically form part of a local cultural infrastructure or will they - as observed in the case of "Soho" - serve the needs of the total population of the city? 
"Soho in Ottakring" and the district's other new cultural facilities have already contributed to an upgrading of the area. Significant trends of gentrification are currently not observable. What has to be improved by the municipality of Vienna is a cultural policy in support of the outskirts' new cultural venues and the provision of appropriate financing.

According to its range of theatres, music venues and other facilities, the cultural infrastructure of the 20th district of Paris is more developed than that of the $16^{\text {th }}$ district in Vienna. As the example of the "Théâtre de l'Est Parisien" shows, the development of peripheral grassroots projects also started earlier in Paris.

Although the $20^{\text {th }}$ district houses some state-subsidised institutions like the TEP or the "Théâtre National de la Colline", the majority of smaller facilities seems to be deliberately refraining from state or municipal cultural policy. In the case of the "Maroquinerie" and the "Flèche d'Or", two facilities studied in detail, this was due to the founders' commitment to grassroots democracy. Until their relaunch in 2003 , these cultural facilities offered participatory or emancipatory events like open scenes for amateur musicians and political debates. Due to the close connection to local residents, the facilities' standing in the area and the share of visitors from the quarter was quite high.

In 2003, the "Maroquinerie" and the "Flèche d'Or" underwent a decisive change. The facilities' cultural programmes were commercialised and streamlined. It will remain to be seen how these changes affect the relationship between the cultural facilities and the local residents and the structure of the respective audiences. As the interview partners pointed out, the cultural venues' activities have already had an impact on the local real-estate market. However, the streamlining of the cultural facilities' programmes and the changes at real-estate market are indicators of gentrification processes currently taking place in the East of Paris.

Finally, the outlined results of previous research work (chapter 2) and the conclusions from the two case-studies (chapters 3 and 4) shall be merged into a tentative typology of the cultural facilities' effects on the development of fringe areas. The two case-studies on Vienna and Paris show that cultural initiatives can stimulate the cultural, economic and social development of peripheral parts of cities. In terms of the facilities' impact on urban fringe areas, a distinction between effects in the field of culture (immediate effects) and consequences for other realms of urban development (indirect outcomes) has to be made.

Possible effects in the cultural field are

- The advancement of the peripheral areas' cultural autonomy,

- An increased democratisation of culture and

- The decentralisation of leisure activities.

Effects on other realms of urban development are

- The encouragement of urban regeneration,

- An improvement in living conditions (problem: gentrification), 
- The creation of jobs and stimulation of creative industries,

- The promotion of retail trade,

- A reduction of leisure-related traffic,

- The integration of different parts of the population,

- An increased political participation of citizens,

- The creation of a distinct identity of the outskirts (especially for areas with recent housing stock) and

- A stronger identification of the population with their habitat.

From the summarised effects it may be seen that cultural facilities are in a position to make a valuable contribution to the creation of vibrant cities. Therefore it is worth the effort to encourage and support cultural initiatives in urban fringe areas. It is up to the respective municipalities to seize the opportunity.

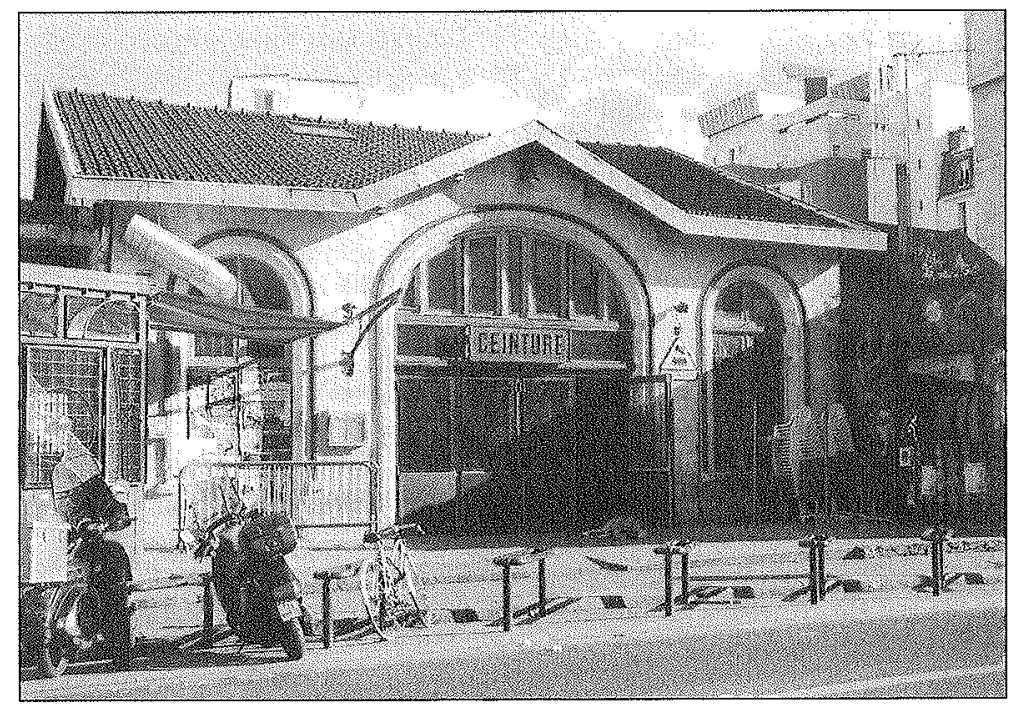

Source: author's photograph

Photo 1: The "Flèche d'Or" 


\section{Note}

1 In this article the terms fringe areas, outskirts, outer districts etc. relate to the peripheral parts of the core city.

\section{References}

Art Position (Ed.) 2003. Art Position 2003. No. 1, May 2003 (programme).

Bacrie, L., 1999. Les camets parisiens: 20e arrondissement. Marché, shopping, artisans, restaurants, sorties, loisirs... (The Parisian booklets: the $20^{\text {th }}$ district. Markets, shopping, craftsmen, restaurants, entertainment, leisure... - in French). Paris (France): Parigramme.

Baeker, G., 2002. "Beyond Garrets and Silos": Concepts, Trends and Developments in Cultural Planning. Municipal Cultural Planning Project Reports. Montreal, Canada, 18 December 2003 (http:// www.culturalplanning.ca/mcpp/mcpp_monograph_may2.pdf)

Bianchini, F., 1993. Remaking European Cities: The Role of Cultural Policies. Cultural Policy and Urban Regeneration: The West European Experience. eds. F. Bianchini \& M. Parkinson. Manchester (UK), New York (USA): Manchester University Press, pp. 1-20.

Centre Tricontinental (Ed.), 2000. Cultures et mondialisation. Résistances et alternatives (Cultures and Globalisation. Resistance and alternatives - in French). Point de vue sud - Centre Tricontinental. Paris (France): L'Harmattan.

Coy, M., 2003. Paris - aktuelle Entwicklungstendenzen und Ansaetze der Stadterneuerung in einer europaeischen Megastadt (Paris - Current Development Trends and First Steps of Urban Renewal in a European Megacity). Petermanns Geographische Mitteilungen 147, 4, pp. 60-69, 2003.

Denizot, M., 1999. Le théâtre de l'Est parisien (the Theatre of the East of Paris - in French). Le XXe arrondissement. La montagne à Paris. eds. F. Gasnault \& J.-Ph. Dumas. Paris (France): Action Artistique de la Ville de Paris, pp. 189-194.

Felonneau, M.-L., 1995. Identité urbaine, identité culturelle (Urban Identity, Cultural Identity - in French). Culture, identité, banlieue. Villes de banlieue: quelle culture pour quelle identité. ed. Ville de Floirac. Bordeaux (France): Éditions de la maison des sciences de l'homme d'Aquitaine:, pp. 75-84.

Florida, R., 2002. The Rise of the Creative Class. And how it's transforming work, leisure, community and everyday life. New York (USA): Basic Books.

Griffiths, R., 1995. Cultural Strategies and New Modes of Urban Intervention. Cities 12, 4, pp. 253-265, 1995.

INST (Ed.), 2003. Cultural Studies and Europe or the Reality of Virtuality. Cultural Concepts. Vienna, Austria, 26 December 2003 (http://www.inst.at/ausstellung/kultbeg_e.htm\#Sahlins)

Koksuz, B., 2001. Cultural Institutions - Urban Renewal Tool. Call for Papers: Abstracts. International Federation for Housing and Planning, International Congress "Urban Renewal", Barcelona, September 9-13 2001, pp. 27-28.

Lextrait, F. et al., 2001. Une nouvelle époque de l'action culturelle. Rapport à Michel Duffour, secrétariat d'État au patrimoine et à la Décentralisation culturelle, Mai 2001 (A New Era of Cultural Action. Report to Michel Duffour, secretary of state for heritage and cultural decentralisation, May 2001 in French). Paris (France): La documentation Française. 
Marchand, B., 1993. Paris, histoire d'une ville. XIXe-XXe siècle (Paris, history of a city. $19^{\text {th }}$ to $20^{\text {th }}$ century - in French). Paris (France): Editions du Seuil.

McCarthy, J., 2002. Entertainment-led Regeneration: The Case of Detroit. Cities 19, 2, pp. 105-111, 2002.

MCPP (Ed.), 2003. Project Information/Information sur le projet. Montreal, Canada, 22 December 2003 (http://www.culturalplanning.ca/mcpp/project_info.html)

Meusy, J.-J., 2001. La Bellevilloise (1877-1939). Une page de l'histoire de la coopération et du mouvement ouvrier français (The Bellevilloise (1877-1939). A page in the history of cooperation and of the French workers' movement -- in French). Paris (France): Créaphis.

Michelin (Ed.), 1994. Michelin Paris. Guide de Tourisme (Michelin Paris. Tourist Guide - in French) Paris: Éditeurs Michelin.

Moulinier, P., 2001. Les politiques publiques de la culture en France (Public Cultural Policies in France - in French). Que sais-je No. 3.427. Paris (France): Presses Universitaires de France.

National Arts Journalism Program (Ed.), 2000. The Big Buildup. Panel on the role of the arts in urban redevelopment, Columbia University, 6 March 2000. New York, USA, 18 December 2003 (http:// www.najp.org/buildup.pdf)

Rohn, W., 2001. New Cultural Institutions in the Outskirts of Vienna. Call for Papers: Abstracts. International Federation for Housing and Planning, International Congress "Urban Renewal", Barcelona, September 9-13 2001, pp. 42-43.

Rohn, W., 2003. Wien. Die neue Kultur an der Peripherie der Stadt (Vienna. New Culture at the City's Periphery - in German). Dérive 4, 2, pp. 30-31, 2003.

Schneider, U. et al. (Ed.), 2003. SOHO in Ottakring. Welten Sichten. 24. Mai - 7. Juni 2003. Programm (Soho in Ottakring. Views of the world. May 24-June 7 2003. Programme - in German). Vienna.

Seo, J.-K, 2002. Re-urbanisation in Regenerated Areas of Manchester and Glasgow. Cities 19, 2, pp. $113-121,2002$.

Time Out (Ed.), 2002. Paris Visitor's Guide 2002/2003. London (UK): Time Out Guides Ltd.

Wehrli-Schindler, B., 2002. Kulturelle Einrichtungen als Impulsgeber fuer Stadtentwicklung?

Beobachtungen am Beispiel Zuerich West (Cultural Institutions as Catalysts for Urban Development? The example of Zuerich West - in German). DISP 38, 3, pp. 4-10, 2002.

Zukin, S., 1998. Staedte und die Oekonomie der Symbole (Cities and the Economy of Symbols - in German). Kultur in der Stadt. Stadtsoziologische Analysen zur Kultur. eds. V. Kirchberg \& A. Goeschel. Opladen (Germany): Leske + Budrich, pp. 27-40. 